\title{
Andrzej Dakowicz
}

University of Bialystok, Poland

\section{MARITAL SUCCESS FROM THE PERSPECTIVE OF KOZIELECKI'S TRANSGRESSION MODEL}

\begin{abstract}
Spouses exhibit two kinds of behaviours: protective and transgressive. Protective acts are those aiming to overcome current problems, leading to preserving some balance. Transgressive acts are deliberately overstepping everyday marital reality and doing new things in new ways. They lead to changing the relation with the hope of improving it, but also create the risk of deterioration. The more transgressive behaviours spouses exhibit, the more chances they have to get to know each other and experience the joy of being part of a union. Transgressive tendencies stem from a network personality structure and consist of five psychons: cognitive, instrumental, motivational, emotional, and personal. The success of a marriage is the effect of a specific form of transgressive behaviours in marriage exhibited by both spouses, which is recognizing difficulties as they appear, finding their sources, and taking steps together to overcome them.
\end{abstract}

\section{Introduction}

In spite of constant socio-cultural change, including the rise of new forms of marital and family life (Walker, 2004), marriage and the family built around it remain an important value for young people all over the world (Whitton et al., 2008). There is no need to prove that a stable, happy marriage and the family built around it are the foundation of a healthy society (Prasad, 2006). At the same time, it is important to notice the increasing trend towards disintegration of marriages at various stages, which should lead to a deeper reflection on the change in the modern understanding of marriage (Cherlin, 2004), as well as research providing a better understanding of the current reality of marital life (Lorenz et al., 2006). Therefore, social science now faces the important task of identifying the factors and mechanisms forming a marital relation that is satisfying for both spouses. Apart from its scientific value, identifying these factors and mechanisms may have important therapeutic and prophylactic value. Many researchers, 
especially couples therapy practitioners, describe in their work the most important factors influencing the quality of a marital relationship, based on various theoretical concepts (e.g. behaviourism, psychoanalysis, humanistic psychology, cognitive psychology). According to Powell (1967) harmony in marriage can be disturbed by the internal blocks and entanglements of emotional life, which make it difficult for the spouses to express their love for each other. Using in practice the rules of constructive controversy (Kratochvil, 2006) or fair marital quarrel (Fischaleck, 1979) allows spouses to both get rid of negative emotions and come closer together. Beck (1989), using the achievements of cognitive psychology, reaches the sources of marital troubles, not focused on discovering traumas from childhood, but on identifying dysfunctional beliefs (e.g., so-called automatic thoughts). Analyzing the available cognitive content helps resolve visible and hidden problems, and gives tips how to do this. Focus forces spouses to understand what is going on in their relationship, and the overthrow of the "marital taboo" can give a firm basis for healthy relationships in the future (Skynner \& Cleese, 1983). Albisetti (2008) proposes three rules for improving a marital relation: be yourselves, be engaged together, and develop together. Crane (1996) sees real hope for couples in therapy in following his steps: 1) identifying the needs of both spouses; 2) controlling the meetings; 3) initiating interaction between the spouses; 4) finding a balance between power, intimacy, and trust; 5) recognizing the style of attribution; 6) identifying the partners' unrealistic expectations; 7) the role, aim, and benefits of housework. Rules for a happy marriage proposed by Gottman and Silver (1999) are the result of years of research and marriage therapy: 1) update your partner's world maps; 2) foster a feeling of friendship and admiration for your partner; 3) turn towards each other, not away from each other; 4) allow yourselves to be influenced by your partner; 5) solve problems which can be solved; 6) overcome the paralyzing conflict; 7) find a feeling of community.

As psychology develops as a science, new theoretical models appear, focusing on various aspects of the human psyche, which are more developed and thus closer to a full description of the variety of the human psyche. One of the most important concepts connected with this, particularly in the context of marital success, is interpersonal communication (Morreale et al., 2001) and personality (Schaffhuser et al., 2014). The cognitive approach, in its many forms, is currently the dominant trend in psychology (Schultz \& Schultz, 2011), so it is reasonable to attempt to take a closer look, from this perspective, at the psychological mechanisms promoting the success of a close interpersonal relation such as marriage. 
One of the newer approaches in cognitive psychology is psychotransgressionism, developed by Kozielecki (2007). A great advantage of this approach is the network theory of personality (NTP) and the suggested explanation for the mechanics of interpersonal communication by referring to two essential types of human action: protective and transgressive. These concepts are particularly useful in realising the goal of this article, which is an attempt to identify patterns in marital relations which increase the likelihood of success of the marriage.

\section{Character of Human (Marital) Activities}

The first type is defensive - palliative, i.e. their aim is to protect from physical and psychological pain and help retain balance. In a marriage they include doing housework, and avoiding provocations, misunderstanding, and conflict. Husband and wife try to perform their tasks well and if problems arise, they try to overcome them using tried and tested methods. Usually they understand their own role and that of their spouse and are fairly predictable to each other. They sacrifice something in order to increase their own value (Taylor, Peplau \& Sears, 2000). Protective actions preserve a marital relation even if it is no longer satisfactory. An important role is played by the course of the marriage relationship because of the exchange process between the spouses considered in terms of rewards or costs. In the case where the balance of such an exchange is relatively positive, beneficial for both partners, the relationship is continued. However, in the case where the balance of exchange is negative from the perspective of both partners, or one of them, the marriage declines, that is, goes back to the early stages of its development and operation, or breaks down completely (Clark \& Mills, 1979; Laurenceau et al., 1998). Research using the exchange theory indicates that factors such as age, lack of experience from earlier relationships, low social activity, lack of belief in control over one's life, and the belief that divorce is the worse option predict the stability of unhappy marriages (Heaton \& Albrecht, 1991).

Transgressive actions are the intentional overstepping of everyday boundaries and doing new things in new ways (Kozielecki, 2007). In a marriage, this means making attempts to improve the relation, make it deeper, at the risk of making the situation worse. Sharing one's doubts and feelings may elicit empathic support and actual help, or lead to the unpleasant experience of being disregarded, misunderstood, or downright ignored. When the husband includes, in his relation to his wife, her perception of mutual 
relation and an understanding of her inner world, she feels that he takes an authentic interest in her. An analogous process takes place when she shows authentic interest in his worldview and personal emotional life. Something happens in their life which they had rarely experienced before in contact with their spouse. This encourages them to be more open towards each other in the future. They are now more likely to share their feelings, experiences, and needs (Altman \& Taylor, 1973). Through such experiences they have a chance to get to know new areas of their inner worlds, which they had not known, for various reasons, and thus had misunderstood.

This creates a new climate in the marriage, encouraging spouses to make further attempts to improve their communication and closeness. They continue trying to reach out to each other and learn something new about each other. If they fail, they are encouraged to try a new approach. They give themselves another chance, because the see that a relation based solely on protective (palliative) activities will not be satisfactory. They seek occasions to take action together, because this leads them to get to know each other better and creates better conditions for personal development. Spouses are fulfilled through cooperation. Choosing the other's good over one's own, they enrich their relationship. Interdependence thus refers to affective interactions between spouses and stresses the importance of the factors intimacy and love, as opposed to independence or attachment, which is close to the essence of the meaning of protective behaviors (Hazan \& Shaver, 1994).

It is very likely that the more transgressive actions spouses take, the more chances they have to learn about themselves and each other and to experience the joy of a bond they want to share. The success of a marriage results from a specific kind of transgressive behaviour expressed by both husband and wife - recognising problems, searching for their origins, and taking steps together to overcome them.

\section{Network Structure of the Personality of Spouses}

The personality of the spouses determines their behaviour in marriage, particularly in the case of transgressive actions. Kozielecki (2007) proposed a new model of personality as a network of five fairly constant and equal elements, called psychons, which function as a whole, cementing identity and enabling interaction with the outside world. This way of approaching personality is similar to the methodology used by Eysenck and Cattell, who focus on determining the structure of the essential characteris- 
tics of personality, recognition of their hierarchical structure, and measurement based on factor analysis (Oleś, 2011). Finally, Eysenck (1990) in their studies focused on three main personality traits: neuroticism, extraversion, and psychoticism. Cattell (1978) identified the most important personality traits as anxiety, integration, and extraversion. A more advanced model of the basic dimensions of personality was developed by Costa and McCrae (1992), who brought it to five personality traits: neuroticism, extraversion, openness to experience, agreeableness, and conscientiousness. Clear recognition of the complex structure of personality in a simple form, as well as the ease of doing research on the basis of ready-made tools, encouraged the practical implementation of research projects using aspects of personality (Periard \& Burns, 2014; Salgado \& Táuriz, 2014), also in the psychological determinants of functioning marriages (Solomon \& Jackson, 2014). But criticism has been directed at this model, in part because it does not include intelligence and motivation, and it is not universally applied (Hough, 1992; Connelly et al., 2014). Kozielecki's (2007) network theory of personality is free from this type of objection and is currently a well-established theoretical proposal for synthesising essential personality traits. In Kozielecki's (2007) network theory of personality, the cognitive psychon includes knowledge (in this case about one's spouse and marriage). It expands one's cognitive space, without which it is hard to imagine maintaining closeness among the turbulence of life (Gottman \& Silver, 1999). Relational judgements, concerning one's relation and the connections between one's self and the outside world, are also an important part of this psychon. They influence people's growing closer or more distant from each other (Mayer, 1998), as well as their perception of themselves leading to tactical self-presentation (either façade or authentic) (Kozielecki, 1987). The cognitive psychon is like a "subjective encyclopaedia" helping one navigate reality (Kozielecki, 2007). The next psychon - instrumental - influences how spouses perform everyday tasks and solve unusual problems. Intelligence, often defined as the ability to cope with new situations by referring to earlier experience, is an important part of this psychon (Sternberg, 1997). There is no doubt that this ability influences the atmosphere in a marriage, where problems either encourage the couple to make an effort to overcome them, or lead to destructive emotional stress. The motivational psychon is based on the needs connected with four worlds: material - vital needs; cognitive (symbolic) - cognitive needs; social - social needs; inner - personal needs. These needs activate the motivational process, establish an overall direction and sustain it, influencing the completion (or discontinuation) of thought or deed (see Levine \& Leven, 1991). The emotional 
psychon consists of permanent neurophysiological and psychological systems, emotional processes, and affects and moods, which are accompanied by somatic changes, characteristic facial expressions, and behaviours (see Ekman, 1992). It is likely that positive feelings play a greater role in transgressive behaviours than negative, which Kozielecki (2007) calls the positive affective shift. The personal psychon is a deep neurophysiological, psychological, and spiritual structure, containing a person's existential and personal data (see Stryker, 1987; Piedmont, 1999; MacDonald, 2000). These are coded in conscious beliefs and unspoken conscious states. The most important are: belief in one's own existence as a person and an agent, affirmation of reality, and belief in one's singularity, integrity, continuity, and uniqueness (Kozielecki, 2007).

The concept of transgression is successfully used in building skill and talent models (Popek \& Bernacka, 2008), education and counselling for adults (Czerkawska, 2012), treatment of persons addicted to alcohol (Ślaski, 2012), description of affective phenomena (Gorbatkow, 2008), risk aversion research (Studenski, 2006), analysis of economic reform processes (Kozielecki, 2006), explaining the mechanism of entrepreneurship (Kwarciak, 2003; Goszczyńska, 2006), managerial success (Strzałecki, 2006), and globalisation (Ledzińska, 2006). It can also be used in an attempt to find the mechanisms of a successful marital relationship. It is, in a sense, a continuation of attempts repeatedly undertaken in science to capture the most important determinants of love, which is a persistent basis for a satisfying marriage. Robert Sternberg (1986) brought love down to three basic components: intimacy, passion, and commitment. David M. Buss (2006) and Douglas T. Kenrick (2006) perceive the essence of mutual love by reference to genetics, evolutionary adaptive modifications stored in specific structures of the human brain. Results of previous studies tend to make further search in the direction of deeper penetration of emotional-cognitive processes, in the course of which a significant role is played by adequate levels of neurohormones, in particular dopamine, norepinephrine, serotonin, and oxytocin (Fisher, 2006; Ortigue et al., 2007).

The prospect of heavily advanced research closely linking medicine and psychology by focusing on the discovery of the function of the nervous system is very promising. One element which is enriching fuller recognition of the functioning of the human psyche is discovering its regularity by testing more and more developed psychological theories which are created as better proposals, free from the weakness of an earlier theory. An example of a new psychological theory is presented in this paper - psychotransgressionism - proposing a comprehensive frame of the human psy- 
che, personality structure, and the mechanisms of dependence in interpersonal relations. The remaining part of this article is devoted to the first and most important step - the operationalization of the network theory of personality (NTP). The next step would be research and statistical analysis of results.

\section{Marital Success as a Result of Cooperation between Spouses - Proposed Operationalization of the Network Theory of Personality (NTP)}

Research tools were selected or created to operationalize five psychons based on the theoretical concept of psychotransgressionism (Kozielecki, 2007).

The cognitive psychon can be studied with the use of the Marital Familiarity Questionaire (Dakowicz, 2012a), which contains questions concerning knowledge about one's spouse divided into four spheres: general, emotional, functional, and values. Ten open-ended items were created for the general sphere, such as "The most liked person in the family" and ten closed items with yes/no answers for the other sphere, such as "My well-being depends significantly on what my spouse is going through" (emotional), "Lack of perspectives discourages him" (operational), "My spouse is mostly fond of material possessions" (values). Respondents answered the questions for each of these spheres about their spouse and later the same questions about themselves. By comparing the two lists one can establish how much overlap there is between them and, in consequence, how well the spouses know each other. The lowest score is 0 (no overlap) and the highest score is 40 (all answers overlap).

The instrumental psychon, which is an important element of intelligence, can be operationalized using a ready battery of tests WAIS-R. It consists of six verbal tests (Information, Comprehension, Arithmetic, Digit Span, Similarities, and Vocabulary) and five performance subtests (Picture Arrangement, Picture Completion, Block Design, Object Assembly, and Digit Symbol). Raw scores in each test turn into conversion results (for each age group there is a separate conversion table), and then calculate the ratios of intelligence in the Scales Verbal, Performance and Full, and the factor: Verbal Comprehension, Spatial Perceptual, Freedom from Distraction (Wechsler, 1981).

The motivational psychon can be analysed with the Individual Needs Test (Dakowicz, 2012a), which helps establish preferences with respect to 
vital, cognitive, social, and personal needs (Reddin, 1991). Respondents are presented with groups of four needs (one from each category) and have four points to distribute in each, giving the greatest number of points to the one which best reflects their aspirations, for example: "I would like to eat better" (vital); "I would like to have more time to think things through" (cognitive); "I would like to have more friends" (social); "I would like my job to bring more prestige" (personal).

The emotional psychon can be diagnosed with a semantic differential - respondents are evaluated with respect to 12 concepts: three existential concepts, such as "life"; three connected with family of origin, such as "childhood"; three connected to current family, such as "spouse"; and three connected with work, such as "gratification" (Babbie, 2007).

The personal psychon can be analysed with the Conscious Personal Beliefs Test (Dakowicz, 2012a), in which respondents use a 5-point scale ( 1 - very rarely, 2 - rarely, 3 - sometimes, 4 - often, 5 - very often) to express their beliefs regarding seven types of feelings which form the essence of the personal psychon, such as "Even though the situation changes, I have the feeling that I remain myself throughout my life".

This operationalization of the Network Theory of Personality (NTP) with respect to a marital relationship is a step towards diagnosing individual pairs towards the success of their marriage and searching for possible patterns. Research conducted so far after the operationalization of the cognitive psychon shows that both wives and husbands satisfied with their relationship were characterized by a greater level of knowledge concerning the sphere of values of their spouses. Husbands happy with the marriage were characterized by a higher level of knowledge regarding the emotional sphere of their wives than husbands unhappy with the marriage (Dakowicz, 2012b). In the case of the psychon incentive, powered by psychological needs, the results of the conducted tests so far indicate greater severity of cognitive needs by wives satisfied with their relationship, while for wives dissatisfied with their marriage there is a greater severity of personal needs (Dakowicz, 2011). The results of research of the semantic differential allowed to capture dependencies associated with the emotional psychon give a clear picture regarding spouses different in their degree of satisfaction with the marriage. Both wives and husbands satisfied with their marriage are clearly characterized by a positive affective shift (Dakowicz, under review). Similarly achieved research results related to the content of the personal psychon, show a definitely higher level of conscious personal beliefs attributed to spouses satisfied with their relationship (Dakowicz, under review). 
Marital success from the perspective of Kozielecki's transgression model

\section{Conclusions}

Creating well developed diagnostic tools would make it possible to quickly and successfully diagnose the strength of individual psychons for both husband and wife and to establish the appropriate direction in psychotherapy, leading to an increase in marital success.

In the spirit of psychotransgressionism, one should, when using the research tools selected for operationalizing individual psychons, attempt to find the psychological conditions of marital success, through tracing correlations between individual psychons, ideally in a dynamic process of marital relations of varying quality. Results indicating a potentially greater strength of some psychons would suggest creating more robust networks, which would increase the likelihood of transgressive behaviours, which allow spouses to recognise problems as they appear, effectively look for their causes, and take steps together to overcome them.

\section{R E F E R E N C E S}

Albisetti, V. (2008). Terapia dell'amore coniugale: Come affrontare i problemi del vivere insieme. Milano: Paoline Edizioni.

Altman, I., \& Taylor, D. (1973). Social penetration: The development of interpersonal relationships. New York: Holt.

Babbie, E. (2007). The practice of social research. Belmont: Thomson Wadsworth.

Beck, A. T. (1989). Love is never enough: How couples can overcome misunderstandings, resolve conflicts and solve relationships problems through cognitive therapy. New York: Harper Collins.

Buss, D. M. (2006). The evolution of love. In R. Sternberg \& K. Weis (Eds.), The new psychology of love (pp. 65-86). New York: Yale University Press.

Cattell, R. B. (1978). The scientific use of factor analysis in behavioral and live sciences. New York: Plenum Press.

Cherlin, A. J. (2004). The deinstitutionalization of American marriage. Journal of Marriage and Family, 66, 848-861.

Clark, M. S., \& Mills, J. (1979). Interpersonal attraction in exchange and communal relationships. Journal of Personality and Social Psychology, 37, 12-24.

Connelly, B. S., Ones, D. S., Davies, S. E., \& Birkland, A. (2014). Opening up openness: A theoretical sort following critical incidents methodology and a meta-analytic investigation of the trait family measures. Journal of Personality Assessment, 96, 17-28.

Costa, P. T., \& McCrae, R. R. (1992). Revised NEO Personality Inventory (NEO$P I-R$ ) and NEO Five-Factor Inventory (NEO-FFI): Professional manual. Odessa, FL: Psychological Assessment Resources. 
Crane, D.R. (1996). Fundamentals of marital therapy. New York: Brunner/Mazel Publishers.

Czerkawska, A. (2012). O transgresji w edukacji dorosłych i poradnictwie. Edukacja Dorostych, 2, 93-109.

Dakowicz, A. (2011). Potrzeby indywidualne małżonków zadowolonych i niezadowolonych ze swojego związku. Edukacja. Studia, badania, innowacje, 3, 99105.

Dakowicz, A. (2012a). Psychologiczna analiza małżonków o wysokim i niskim poziomie transgresji. In T. Rostowska \& A. Lewandowska-Walter (Eds.), Mał̇̇éstwo $i$ rodzicielstwo a zdrowie (pp. 79-101). Toruń: Wydawnictwo Adam Marszałek.

Dakowicz, A. (2012b). Wiedza na temat współmałżonka w małżeństwach zadowolonych i niezadowolonych ze swojego związku. In A. Mitręga \& I. Jagoszewska (Eds.), Komunikacja jako narzędzie (po)rozumienia we wspólnotach społecznych (pp. 49-58). Toruń: Wydawnictwo Adam Marszałek.

Dakowicz, A. (under review). Specyfika sfery afektywnej małżonków zadowolonych i niezadowolonych ze swojego związku.

Dakowicz, A. (under review). Świadomość osobistych przekonań małżonków zadowolonych i niezadowolonych ze swojego związku.

Ekman, P. (1992). Telling lies: Clues to deceit in the marketplace, politics and marriage. New York: W. W. Norton.

Eysenck, H. J. (1990). Biological dimensions of personality. In L. A. Pervin (Ed.), Handbook of personality: Theory and research (pp. 244-276). New York: Guilford Press.

Fischaleck, F. (1979). Faires Streiten in der Ehe: Partnerkonflikte besser lösen. Freiburg im Breisgau - Basel - Wien: Herder.

Fisher, H. (2006). The drive to love: The neural mechanisms for mate selection. In R. Sternberg \& K. Weis (Eds.), The new psychology of love (pp. 87-115). New York: Yale University Press.

Gorbatkow, A. (2008). Pozytywno-negatywna asymetria emocji a rozwój podmiotowy jednostki. In I. Pufal-Struzik (Ed.), O przekraczaniu granic własnych ograniczeń - z perspektywy psychotransgresjonizmu (pp. 97-112). Kraków: Oficyna Wydawnicza "Impuls".

Goszczyńska, M. (2006). Działania przedsiębiorcze - przejaw przystosowania czy transgresji. In E. Aranowska \& M. Goszczyńska (Eds.), Człowiek wobec wyzwań i dylematów współczesności. Ksiega jubileuszowa dedykowana Profesorowi Józefowi Kozieleckiemu (pp. 189-207). Warszawa: Wydawnictwo Naukowe SCHOLAR.

Gottman, J. M., \& Silver, N. (1999). The seven principles for making marriage work. New York: Crown.

Hazan, C., \& Shaver, P. R. (1994). Attachment as an Organizational Framework for Research on Close Relationships. Psychological Inquiry, 5, 1-22. 
Heaton, T. B., \& Albrecht, S. L. (1991). Stable unhappy marriages. Journal of Marriage and the Family, 53, 747-758.

Hough, L. M. (1992). The 'Big Five' Personality Variables - Construct Confusion: Description Versus Prediction. Human Performance, 5, 139-155.

Kenrick, D. T. (2006). Dynamical evolutionary view of love. In R. Sternberg \& K. Weis (Eds.), The new psychology of love (pp. 15-34). New York: Yale University Press.

Kozielecki, J. (1987). Koncepcja transgresyjna człowieka. Warszawa: PWN.

Kozielecki, J. (2006). Reforma polskiej gospodarki: studium decyzji transgresyjnych. In: E. Aranowska \& M. Goszczyńska (Eds.), Człowiek wobec wyzwań i dylematów współczesności (pp. 17-43). Warszawa: Wydawnictwo Naukowe SCHOLAR.

Kozielecki, J. (2007). Psychotransgresjonizm: Nowy kierunek psychologii. Warszawa: Wydawnictwo Akademickie "Żak".

Kratochvil, S. (2006). Terapia matżeńska. Gdańsk: Wydawnictwo Via Medica.

Kwarciak, K. (2003). Psychologiczne wyznaczniki skutecznego przedsiębiorcy. Acta Uniwersitatis Wratislaviensis, No. 2535, Prace Psychologiczne LVII, 145153.

Laurencean, J. P., Barrett, L. F., \& Pietromonaco, P. R. (1998). Intimacy as an interpersonal process: The importance of self-disclosure, partner disclosure, and perceived partner responsiveness in interpersonal exchanges. Journal of Personality and Social Psychology, 74, 1238-1251.

Levine, D. S., \& Leven, S. J. (Eds.) (1991). Motivation, emotion, and goal direction in neural networks. New York: Psychology Press.

Lorenz, F. O., Wickrama, K. A. S., Gonger, R. D., \& Elder Jr., G. H. (2006). The short-term and decade-long effects of divorce on women's midlife health. Journal of Health and Social Behavior, 4\%, 111-125.

Mayer, J. D. (1998). A systems framework for the field of personality. Psychological Inquiry, 9, 118-144.

McDonald, D. A. (2000). Spirituality: Description, measurement, and relation to the Five Factor Model of Personality. Journal of Personality, 1, 153-198.

Morreale, S. P., Spitzberg, B. H., \& Barge, J. K. (2001). Human communication: Motivation, knowledge and skills. Wadsworth: Thomson Learning Inc.

Oleś, P. K. (2011). Wprowadzenie do psychologii osobowości. Warszawa: Wydawnictwo Naukowe SCHOLAR.

Ortigue, S., Bianchi-Demicheli, F., Hamilton, A. F. de C., \& Grafton, S. T. (2007). The neural basis of love as a subliminal prime: An event-related functional magnetic resonance imaging study. Journal of Cognitive Neuroscience, 19, $1218-1230$.

Periard, D. A., \& Burns, G. N. (2014). The relative importance of Big Five Facets in the prediction of emotional exhaustion. Personality and Individual Differences, 63, 1-5. 
Piedmont, R. L. (1999). Does spirituality represents the sixth factor of personality? Spiritual Transcendence and the Five-Factor Model. Journal of Personality, 6, 985-1013.

Popek, S., \& Bernacka, R. E. (2008). Zdolności i uzdolnienia - ujęcie transgresyjne. In I. Pufal-Struzik (Ed.), O przekraczaniu granic wtasnych ograniczeń - z perspektywy psychotransgresjonizmu (pp. 13-21). Kraków: Oficyna Wydawnicza "Impuls".

Powell, J. (1967). Why am I afraid to love? Chicago: Argus Communications Co.

Prasad, G. (2006). The great Indian family: New roles - old responsibilities. New Delhi: Penguin Books.

Reddin, B. (1991). Tests for the output oriented manager: A self-assessment guide. London: Kogan.

Salgado, J. F., \& Táuriz, G. (2014). The Five-Factor Model, forced-choice personality inventories and performance: A comprehensive meta-analysis of academic and occupational validity studies. European Journal of Work and Organizational Psychology, 23, 3-30.

Schaffhuser, K., Allemand, M., \& Martin, M. (2014). Personality traits and relationship satisfaction in intimate couples: Three perspectives on personality. European Journal of Personality, 2, 120-133.

Schultz, D. P., \& Schultz, S. E. (2011). A History of modern psychology (10th ed.). Wadsworth: Cengage Learning.

Skynner, R., \& Cleese, J. (1983). Families and how to survive them. London: Methuen.

Solomon, B. C, \& Jackson, J. J. (2014). Why do personality traits predict divorce? Multiple pathways through satisfaction. Journal of Personality and Social Psychology, 6, 978-996.

Sternberg, R. J. (1986). A triangular theory of love. Psychological Review, 93, 119135.

Sternberg, R. J. (1997). Introduction to psychology. Orlando: Harcourt Brace College Publishers.

Stryker, S. (1987). Identity theory: Developments and extensions. In K. Yardley \& T. Honess (Eds.), Self and identity: Psychological perspectives (pp. 89103). Chichester: Wiley.

Strzałecki, A. (2006). Transgresja polskich menedżerów w warunkach transformacji ustrojowej. In E. Aranowska \& M. Goszczyńska (Eds.), Człowiek wobec wyzwań i dylematów wspótczesności (pp. 108-132). Warszawa: Wydawnictwo Naukowe SCHOLAR.

Studenski, R. (2006). Skłonność do ryzyka a zachowania transgresyjne. In M. Goszczyńska \& R. Studenski (Eds.), Psychologia zachowań ryzykownych: Koncepcje, badania, praktyka (pp. 128-142). Warszawa: Wydawnictwo Akademickie "ŻAK". 
Marital success from the perspective of Kozielecki's transgression model

Ślaski, S. (2012). Motywacyjno-osobowościowe wyznaczniki zachowań transgresyjnych $i$ ochronnych. Warszawa: Wydawnictwo Uniwersytetu Stefana Kardynała Wyszyńskiego.

Taylor, S. E., Peplau, L. A., \& Sears, D. O. (2000). Social psychology. New Jersey: Prentice Hall.

Walker, A. (2004). A symposium on Marriage and its Future. Journal of Marriage and Family, 66, 843-847.

Wechsler, D. (1981). Wechsler Adult Intelligence Scale-Revised. San Antonio: Psychological Corporation.

Whitton, S. W., Rhoades, G. K., Stanley, S. M., \& Markman, H. J. (2008). Effects of parental divorce on marital commitment and confidence. Journal of Family Psychology, 22, 789-793. 